\title{
Front Matter: Volume 7561
}

, "Front Matter: Volume 7561," Proc. SPIE 7561, Optical Biopsy VII, 756101 (10 March 2010); doi: 10.1117/12.858676

SPIE. Event: SPIE BiOS, 2010, San Francisco, California, United States 


\section{PROGRESS IN BIOMEDICAL OPTICS AND IMAGING}

Vol. 11, No. 14

\section{Optical Biopsy VII}

Robert R. Alfano

Editor

25-28 January 2010

San Francisco, California, United States

Sponsored by

SPIE

Cosponsored by

Ocean Optics, Inc.

Published by

SPIE

Volume 7561

Proceedings of SPIE, 1605-7422, v. 7561

SPIE is an international society advancing an interdisciplinary approach to the science and application of light. 
The papers included in this volume were part of the technical conference cited on the cover and title page. Papers were selected and subject to review by the editors and conference program committee. Some conference presentations may not be available for publication. The papers published in these proceedings reflect the work and thoughts of the authors and are published herein as submitted. The publisher is not responsible for the validity of the information or for any outcomes resulting from reliance thereon.

Please use the following format to cite material from this book:

Author(s), "Title of Paper," in Optical Biopsy VII, edited by Robert R. Alfano, Proceedings of SPIE Vol. 7561 (SPIE, Bellingham, WA, 2010) Article CID Number.

ISSN 1605-7422

ISBN 9780819479570

Published by

SPIE

P.O. Box 10, Bellingham, Washington 98227-0010 USA

Telephone +1 3606763290 (Pacific Time) · Fax +1 3606471445

SPIE.org

Copyright $@ 2010$, Society of Photo-Optical Instrumentation Engineers.

Copying of material in this book for internal or personal use, or for the internal or personal use of specific clients, beyond the fair use provisions granted by the U.S. Copyright Law is authorized by SPIE subject to payment of copying fees. The Transactional Reporting Service base fee for this volume is $\$ 18.00$ per article (or portion thereof), which should be paid directly to the Copyright Clearance Center (CCC), 222 Rosewood Drive, Danvers, MA 01923. Payment may also be made electronically through CCC Online at copyright.com. Other copying for republication, resale, advertising or promotion, or any form of systematic or multiple reproduction of any material in this book is prohibited except with permission in writing from the publisher. The CCC fee code is 1605$7422 / 10 / \$ 18.00$.

Printed in the United States of America.

Publication of record for individual papers is online in the SPIE Digital Library.

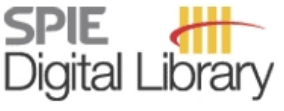

SPIEDigitalLibrary.org

Paper Numbering: Proceedings of SPIE follow an e-First publication model, with papers published first online and then in print and on CD-ROM. Papers are published as they are submitted and meet publication criteria. A unique, consistent, permanent citation identifier (CID) number is assigned to each article at the time of the first publication. Utilization of CIDs allows articles to be fully citable as soon they are published online, and connects the same identifier to all online, print, and electronic versions of the publication. SPIE uses a six-digit CID article numbering system in which:

- The first four digits correspond to the SPIE volume number.

- The last two digits indicate publication order within the volume using a Base 36 numbering system employing both numerals and letters. These two-number sets start with $00,01,02,03,04$, $05,06,07,08,09,0 A, 0 B \ldots$. 0Z, followed by 10-1Z, 20-2Z, etc.

The CID number appears on each page of the manuscript. The complete citation is used on the first page, and an abbreviated version on subsequent pages. Numbers in the index correspond to the last two digits of the six-digit CID number. 


\title{
Contents
}

\author{
vii Conference Committee \\ ix Introduction
}

SESSION 1 FLUORESCENCE AND RAMAN DIAGNOSIS I

756103 Visualization of epithelial morphology using autofluorescence microscopy under ultraviolet excitation [7561-02]

B. Lin, Univ. of California, Davis (United States); S. Urayama, R. M. G. Saroufeem, Univ. of California, Davis Medical Ctr. (United States); D. L. Matthews, Univ. of California, Davis (United States); S. G. Demos, Univ. of California, Davis (United States) and Lawrence Livermore National Lab. (United States)

756104 Advances in handheld spectral sensors and systems (Invited Paper) [7561-03] J. M. Eichenholz, J. McCaffrey, Ocean Optics, Inc. (United States); J. Lane, Ocean Thin Films, Inc. (United States)

756107 UV extended supercontinuum source for time resolved and steady state spectroscopy for biological and chemical molecules [7561-06]

R. R. Alfano, V. Kartazaev, I. Zeylikovich, B. Das, The City College of New York (United States); D. Nolan, Corning Inc. (United States)

756109 Optical spectroscopy approach for the predictive assessment of kidney functional recovery following ischemic injury [7561-08]

R. N. Raman, Lawrence Livermore National Lab. (United States); C. D. Pivetti, Univ. of California, Davis Medical Ctr. (United States); A. M. Rubenchik, Lawrence Livermore National Lab. (United States); D. L. Matthews, Univ. of California, Davis (United States); C. Troppmann, Univ. of California, Davis Medical Ctr. (United States); S. G. Demos, Lawrence Livermore National Lab. (United States)

7561 OA Rotational dynamics and polarization anisotropy of bound and unbound receptor-targeted contrast agents in cancerous and normal prostate tissues studied by time-resolved fluorescence spectroscopy [7561-09]

Y. Pu, W. B. Wang, The City College of New York (United States); S. Achilefu, Washington Univ. School of Medicine (United States); R. R. Alfano, The City College of New York (United States)

7561 OB Stokes shift spectroscopy for breast cancer diagnosis [7561-11]

E. Jeyasingh, Jamal Mohamed College (India); A. Prakashrao, G. Singaravelu, Anna Univ. (India)

\section{SESSION 2 QUANTUM COHERENT EFFECTS IN BIOLOGY AND MEDICINE}

7561 OC From Förster resonance energy transfer to coherent resonance energy transfer and back (Invited Paper) [7561-12]

R. M. Clegg, M. Sener, Govindjee, Univ. of Illinois at Urbana-Champaign (United States) 
7561 OD Quantum effects in biological systems (Invited Paper) [7561-13]

M. Sarovar, Univ. of California, Berkeley (United States)

\section{SESSION 3 FLUORESCENCE AND RAMAN DIAGNOSIS II}

$7561 \mathrm{OH} \quad$ Telegrapher-based fluorescence-enhanced optical tomography in small volume [7561-17]

R. Roy, The Univ. of Texas-Pan American (United States)

7561 0J Polarized fluorescence study in human cervical tissue: change in autofluorescence through different excitation wavelengths [7561-19]

R. Singh, K. K. S. Tomar, M. Majumdar, P. Shukla, A. Pradhan, Indian Institute of Technology Kanpur (India); R. Gupta, S. Jain, C. Pantola, A. Agarwal, K. Pandey, Ganesh Shanker Vidyarthi Memorial Medical College (India)

\section{SESSION 4 IMAGING DIAGNOSIS}

7561 ON Multimodality optical imaging combining optical coherence tomography (OCT) and fluorescence lifetime imaging (FLIM) for morphological and biochemical tissue characterization [7561-23]

S. Shrestha, J. Park, P. Pande, B. E. Applegate, J. A. Jo, Texas A\&M Univ. (United States)

756100 Multispectral imaging techniques observing the dynamic changes in the hemoglobin concentrations as diagnostic tool for diseased tissues [7561-24]

J. H. G. M. Klaessens, H. J. Noordmands, R. de Roode, Univ. Medical Ctr. Utrecht (Netherlands); R. M. Verdaasdonk, Free Univ. Medical Ctr. (Netherlands)

$75610 Q \quad$ Tissue characterization by using narrow band imaging (Invited Paper) [7561-26]

K. Gono, Olympus Medical Systems Corp. (Japan)

7561 OT Diffuse reflectance spectroscopy of pre- and post-treated oral submucous fibrosis: an in vivo study [7561-29]

S. Sivabalan, Anna Univ. Chennai (India); C. Ponranjini Vedeswari, S. Jayachandran, Tamilnadu Government Dental College and Hospital (United States); D. Koteeswaran, C. Pravda, Meenakshi Ammal Dental College and Hospital (United States); P. Aruna,

S. Ganesan, Anna Univ. Chennai (India)

\section{SESSION 5 BIOPHOTONIC APPROACH FOR DISEASE AND VIRUS DETECTION}

7561 OW Photonic approach to the selective inactivation of viruses with a near-infrared ultrashort pulsed laser (Invited Paper) [7561-32]

K. T. Tsen, Arizona State Univ. (United States); S.-W. D. Tsen, Washington Univ. School of Medicine (United States); Q. Fu, S. M. Lindsay, K. Kibler, B. Jacobs, Arizona State Univ. (United States); T. C. Wu, The Johns Hopkins Medical Institutions (United States); Z. Li, H. Yan, S. Cope, S. Vaiana, Arizona State Univ. (United States); J. G. Kiang, Uniformed Services Univ. of the Health Sciences (United States)

7561 0X The importance of optical methods for non-invasive measurements in the skin care industry (Invited Paper) [7561-33]

G. N. Stamatas, Johnson \& Johnson Consumer France (France) 
756112 Differentiation of normal and cancerous lung tissues by multiphoton imaging [7561-38]

C.-C. Wang, F.-C. Li, R.-J. Wu, V. A. Hovhannisyan, National Taiwan Univ. (Taiwan); W.-C. Lin, National Taiwan Univ. Hospital (Taiwan); S.-J. Lin, National Taiwan Univ. (Taiwan) and National Taiwan Univ. Hospital (Taiwan); P. T. C. So, Massachusetts Institute of Technology (United States); C.-Y. Dong, National Taiwan Univ. (Taiwan)

\section{POSTER SESSION}

756114 Healing and evaluating guinea pig skin incision after surgical suture and laser tissue welding by using in vivo Raman spectroscopy [7561-40]

A. Alimova, V. Sriramoju, R. Chakraverty, R. Muthukattil, R. R. Alfano, The City College of New York (United States)

756115 Changes of collagen, elastin, and tryptophan contents in laser welded porcine aorta tissues studied using fluorescence spectroscopy [7561-41]

C.-H. Liu, W. B. Wang, V. Kartazaev, The City College of New York (United States); H. Savage, The New York Eye and Ear Infirmary (United States); R. R. Alfano, The City College of New York (United States)

756116 Optical birefringence of aorta tissues [7561-42]

G. C. Tang, W. B. Wang, Y. Pu, R. R. Alfano, The City College of New York (United States)

756117 Development of optical mammography based on analysis of time-resolved photon path distribution [7561-43]

Y. Ueda, D. Yamashita, K. Yoshimoto, E. Ohmae, T. Suzuki, T. Yamanaka, Hamamatsu Photonics K.K. (Japan); H. Ogura, C. Teruya, H. Nasu, E. Imi, H. Sakahara, Hamamatsu Univ. School of Medicine (Japan); M. Oda, Y. Yamashita, Hamamatsu Photonics K.K. (Japan)

756118 Application of NIR fluorescent markers to quantify expression level of HER2 receptors in carcinomas in vivo [7561-50]

V. Chernomordik, M. Hassan, S. B. Lee, R. Zielinski, J. Capala, A. Gandjbakhche, National Institutes of Health (United States)

Author Index 
Downloaded From: https://www.spiedigitallibrary.org/conference-proceedings-of-spie on 26 Apr 2023

Terms of Use: https://www.spiedigitallibrary.org/terms-of-use 


\title{
Conference Committee
}

\author{
Symposium Chairs \\ James G. Fujimoto, Massachusetts Institute of Technology (United \\ States) \\ R. Rox Anderson, Wellman Center for Photomedicine, Massachusetts \\ General Hospital (United States) and Harvard School of Medicine \\ (United States)
}

Program Track Chairs

Tuan Vo-Dinh, Duke University (United States)

Anita Mahadevan-Jansen, Vanderbilt University (United States)

Conference Chair

Robert R. Alfano, The City College of New York (United States)

Conference Cochair

Stavros G. Demos, Lawrence Livermore National Laboratory (United States)

Program Committee

Stefan K. Andersson, Lund University (Sweden)

Britton Chance, University of Pennsylvania (United States)

Christopher H. Contag, Stanford University School of Medicine (United States)

Amir H. Gandjbakhche, National Institutes of Health (United States)

Israel Gannot, George Washington University (United States) and Tel Aviv University (Israel)

Richard B. Rosen, The New York Eye and Ear Infirmary (United States)

Masood Siddique, The City College of New York (United States)

Urs Utzinger, The University of Arizona (United States)

Wubao B. Wang, The City College of New York (United States)

Webb W. Watt, Cornell University (United States)

\section{Session Chairs}

1 Fluorescence and Raman Diagnosis I

Stavros G. Demos, Lawrence Livermore National Laboratory (United States)

2 Quantum Coherent Effects in Biology and Medicine

Robert R. Alfano, The City College of New York (United States) 
3 Fluorescence and Raman Diagnosis II

Jason M. Eichenholz, Ocean Optics, Inc. (United States)

$4 \quad$ Imaging Diagnosis

Wubao Wang, The City College of New York (United States)

5 Biophotonic Approach for Disease and Virus Detection

Stavros G. Demos, Lawrence Livermore National Laboratory (United States) 


\section{Introduction}

The conference Optical Biopsy VIII was held at the BiOS in SPIE Photonics West in San Francisco under the "Biomedical Spectroscopy, Microscopy and Imaging" and "Clinical Technologies and Systems" tracks on January 25-28, 2010. The optical biopsy field has grown tremendously in terms of researchers involved, manuscripts, and patents published, but most importantly, in terms of the recognition and acceptance of its potential by the medical community and medical devices manufacturers. At the same time, progress in basic research resulted in new ways or improvements in already developed methods that will make the in vivo optical pathology techniques more relevant for translation to a clinical setting and more attractive from a business point of view. These exciting developments will help further grow this field. The effort and level of funding are expected to grow as more interested parties (namely the industrial and the venture capital communities) are expected to participate and be part of the development of the next generation medical devices. These new devices are expected to be based on light-related technologies since light can offer the desired spatial resolution, while the spectral domain can offer the noninvasive in situ diagnostic information. The optical biopsy is and will remain at the core of these biomedical developments.

The conference on Optical Biopsy VIII was well attended by scientists from around the world. The conference consisted of five oral sessions and one poster session for a total of 44 papers presented. Among them, there are 12 invited talks, 26 oral, and 6 poster presentations. The papers presented encompassed several different spectral and imaging technologies: fluorescence and Raman diagnosis; quantum coherent effects in biology and medicine; tissue native emission and contrast agents imaging diagnosis; and biophotonic approaches for disease and virus detections. The invited talks on coherence in biology drew a large audience and interest, and may represent a growth area that has been overlooked in the past. The oral presentations on Stokes Shift Spectroscopy for cancer diagnosis and the UV supercontinuum used for ideal excitation source for native fluorescence spectroscopy may have been potential part of the most innovative presentations.

One could recognize that a large percentage of the attendees were from the industrial community. The invited talks by key leaders in the industrial community highlighted that they are now actively involved or carefully watching the rapid development of optical biopsy technologies. We expect this trend to continue especially as the world's economies emerge from the current downturn. Another trend observed during the years is the translation of research from the optical bench in the early years toward the bedside. A large number of the papers presented were dealing with the imaging of tissue at the microscopy level, demonstrating that optical techniques can capture cellular morphology and 
organization in a manner similar to that provided by the current gold standard pathology based on extracting and staining tissue specimens. A number of talks focused on the use of spectroscopy to obtain information in real time including cancer detection, underlying conditions to skin appearance, and response to ischemia. We expect in the next conference to see more papers dealing with in vivo applications.

The attendees appreciated the talks from all of the invited speakers; in particular, the talks from pioneers and outstanding scientists: Professors Govindjee, Fleming, Matthews, and Lewis, and the corporate mangers from GE-Siavash Yazdanfar, Olympus-Kazuhiro Gono, J\&J-Georgios Stamatas, and Ocean Optics-Jason Eichenholz, for their efforts for the review talks.

We wish to thank Dr. Rob Randleman of Ocean Optics for support, and the session chairs and SPIE staff for their help in making this a successful conference.

Robert R.Alfano

Stavros G. Demos Wubao B. Wang 